\title{
Marta Balcerek-Kosiarz
}

Zakład Badań Władzy Lokalnej i Samorządu Wydział Nauk Politycznych i Dziennikarstwa Uniwersytet im. A. Mickiewicza w Poznaniu e-mail:marta.balcerek@amu.edu.pl

\section{Rola samorządu gminnego w multi-level governance w Republice Federalnej Niemiec ${ }^{1}$}

\section{STRESZCZENIE}

Celem artykułu jest zaprezentowanie, $w$ jaki sposób koncepcja multi-level governance została dostosowana do specyfiki niemieckiego samorządu gminnego oraz na czym polega jej istota. Autorka doszła do dwóch ustaleń. Po pierwsze, powstanie multi-level governance w Niemczech oparte jest na działaniach odgórnych i następuje od kraju związkowego do gmin (top-down). Tworzenie układu sieciowego wynika wówczas z przekonania władz państwowych o efektywniejszej realizacji zadań publicznych opartej na współpracy z podmiotami prywatnymi, których działania moderowane są przez podmioty władcze. Po drugie, wprowadzenie multi-level governance na poziomie lokalnym poprzedzone jest regional governance na szczeblu krajów związkowych stanowiącą dostosowanie koncepcji governance do specyfiki państwa federalnego. Najważniejszym jednak wnioskiem płynącym $\mathrm{z}$ artykułu jest ten, że multi-level governance zostało wprowadzono w strukturę samorządu gminnego za pośrednictwem specjalnego typu zadań publicznych (Gemeinschaftsaufgaben).

SŁOWA KLUCZOWE

Governance, multi-level governance, samorząd gminny, Niemcy

\section{Geneza multi-level governance w RFN}

W niemieckiej literaturze przedmiotu strategia multi-level governance wywodzi się od pojęcia governance. W Wielkiej Brytanii, Irlandii i Stanach Zjednoczonych jest to widoczne w przekazywaniu kompetencji w zakresie koordynacji polityk publicznych na zasadzie dekoncentracji ${ }^{2}$. Na gruncie anglosaskim termin governance rozumiany jako rządzenie lub zarządzanie jest przedmiotem pogłębionych studiów obejmujących następujące zagadnienia:

1 Projekt został sfinansowany ze środków Narodowego Centrum Nauki przyznanych na podstawie decyzji numer DEC-2012/07/N/HS5/01705.

2 C. Ansell, The networked policy. Regional development in Western Europe, „Governance” 2000, Vol. 13, Issue 2, s. 279-291. 
- koordynację polityk publicznych organów administracji publicznej, czyli rządowej i samorządowej,

- analizę narzędzi, jakimi dysponują podmioty publiczne i prywatne w osiągnięciu rozwoju regionalnego i lokalnego,

- wyznaczanie granic i sposobów interwencji władzy publicznej na rynku,

- sposób sprawowania władzy ${ }^{3}$,

- metody współpracy i negocjacji, a nie przymusu',

- relacje między grupami podmiotów w sieci ${ }^{5}$.

$\mathrm{W}$ niemieckiej literaturze przedmiotu podkreśla się także, że governance powstało w RFN w latach 70. ubiegłego wieku w wyniku zmian, które miały miejsce w trzech obszarach: po pierwsze, doszło do szerokiego rozpowszechnienia adaptacji nowego zarządzania publicznego i partnerstw publiczno-prywatnych. Po drugie, nastąpiło w Niemczech rosnące zaangażowanie lokalnych stowarzyszeń, grup interesu i aktorów prywatnych w tworzeniu polityki lokalnej opartej na partnerstwie zainteresowanych podmiotów społeczeństwa obywatelskiego (policy partnership). Po trzecie, wprowadzono w RFN nowe formy zaangażowania obywatelskiego ${ }^{6}$. Po czwarte, kontynuowano w Niemczech szerokie przymierze współpracy między samorządem terytorialnym szczebla gminnego a instytucjami samorządu gospodarczego w szczególności z izbami przemysłowo-handlowymi.

W niemieckiej literaturze przedmiotu, aby odróżnić pojęcie anglosaskie governance, wprowadzono w 2003 r. termin regional governance, który oznacza „słabo zinstytucjonalizowane formy wykonywania zadań o charakterze kooperacji sieciowej regionalnych aktorów stworzone w celu osiągnięcia rozwoju regionalnego"7. Warto również w tym względzie przytoczyć wyjaśnienie Dietricha Fürsta, który wskazał na to, że „regional governance oparte jest na sieciowej współpracy podmiotów z trzech sektorów: polityki, gospodarki oraz społeczeństwa. Podstawą ich działania jest wspólne przygotowanie strategii rozwoju regionalnego" ${ }^{8}$. W celu dopełnienia ujęcia definicyjnego regional governance należy mieć na uwadze także na jego cechy, do których zalicza się: dobrowolne członkostwo zarówno podmiotów publicznych, jak i prywatnych, brak określonych reguł działania, niski stopień zinstytucjonalizowania, funkcjonowanie oprócz zhierarchizowanej administracji rządowej oraz współdziałanie instytucji o różnych interesach, których realizacja możliwa jest tylko w ramach kooperacji?.

3 D. Kaufmann, A. Kraay, M. Mastruzzi, Governance Matters VII: Governance Indicators for 1996-2007, DC World Bank, Washington 2009, s. 1-103.

4 C. Ansell, op. cit.

5 B. Jessop, Promowanie dobrego rządzenia i ukrywanie jego słabości. Refleksja nad politycznymi paradygmatami i politycznymi narracjami w sferze rządzenia, „Zarządzanie Publiczne” 2007, nr 2, s. 5-25.

6 B. Denters, L. Rose, Towards local governance?, w: Comparing Local Governance. Trends and Developments, red. B. Denters, L. Rose, Palgrave Mac Millan, New York 2005, s. 46-62.

7 A. Benz, D. Fürst, Region-Regional Governance-Regionalentwicklung, w: Regionen erfolgreich steuern, red. B. Adamaschek, M. Pröhl, Unversitätsverlag Göttingen, Göttingen 2003, s. 1-123.

8 D. Fürst, Regional Governance - ein neues Paradigma der Regionalwissenschaften?, „Raumforschung und Raumordnung" 2001, No. 59, s. 370-380.

9 D. Fürst, Regional Governance, w: Governance - Regieren in komplexen Regelsystmen, red. A. Benz, VS Verlag für Sozialwissenschaften, Wiesbaden 2004, s. 49-69. 
Proces adaptacji strategii governance w Niemczech miał być dostosowany do specyfiki ustroju federalnego. Podobieństwem w ujęciu anglosaskim i niemieckim jest fakt, że w obu koncepcjach governance jest formą pośrednią zarządzania publicznego. W ujęciu anglosaskim występuje w ramach hierarchii administracji rządowej. W Niemczech natomiast realizowane jest $\mathrm{w}$ ramach zdecentralizowanych struktur organizacyjnych, które zostały wyposażone we władztwo administracyjne pozwalające kształtować prawa i je egzekwować od osób funkcjonujących na ich obszarze ${ }^{10}$. Jako „trzecia droga” pozwala zatem na stworzenie szerokiej partycypacji podmiotów znajdujących się w otoczeniu jednostek samorządu terytorialnego w budowaniu przymierza dla sprawniejszego wykonywania i zarządzania zadaniami publicznymi.

Na podstawie omówionego zakresu przedmiotowego governance nasuwa się wniosek, że trudno jest rozpatrywać tę koncepcję dla jednostek samorządu terytorialnego będących zdecentralizowanymi formami administracji publicznej według kryteriów anglosaskich. Należałoby zatem zastanowić się nad stworzeniem osobnego ujęcia governance dla krajów, w których występuje zdecentralizowana administracja publiczna. Stąd też, odnosząc się do wcześniej wskazanych kryteriów, można przyjąć, że governance w ramach zdecentralizowanej administracji publicznej charakteryzuje się:

- koordynacją polityk publicznych, którym odpowiadają powierzone w ustawach zadania wykonywane zgodnie ze specyfiką danego obszaru,

- analizą funkcjonowania zarówno publicznoprawnych, jak i prywatnoprawnych form organizacyjno-prawnych wykonywania zadań własnych i zleconych,

- sprawdzeniem efektywności wykonywanych zadań z perspektywy osiągniętych celów,

- działaniem podejmowanym przez samorząd gminny w celu rozwoju przedsiębiorczości na jego terenie,

- zbadaniem zakresu interwencji na rynku lokalnym przez pryzmat sprawowania administracji władczej i administracji świadczącej,

- zestawieniem form współdziałania jednostek samorządu terytorialnego na przykładzie: związków celowych (Zweckverbände), komunalnych zespołów roboczych (kommunale Arbeitsgemeinschaft) oraz porozumień publicznoprawnych (öffentliche Vereinbarungen), kształtowaniem przez jednostki samorządu terytorialnego relacji między grupami w sieci na podstawie jednostronnych aktów władczych.

Na podstawie przedstawionych elementów można stwierdzić, że zmianie uległa rola władz publicznych, która w mniejszym stopniu dotyczy kreowania polityki, a o wiele bardziej koncentruje się na moderowaniu różnych aspektów lokalnych polityk publicznych odpowiadających określonym zadaniom powierzonym w ustawach. Administracja publiczna ujmowana $\mathrm{w}$ kategoriach governance, w tym jej tak istotny element, jakim jest samorząd, stanowi zatem część mechanizmów życia społeczeństwa, uczestniczącą w rozwiązywaniu problemów zbiorowych przy udziale zainteresowanych jednostek i grup lub ich przedstawicieli.

10 M. Böcher, Instrumentenwandel in der Umwelt- und Naturschutzpolitik und der Politik zur integrierten ländlichen Entwicklung. Theoretische Grundlagen und Strategien der Praxisumsetzung, Dissertation, Göttingen 2008, s. 1-208. 
Podsumowując, należy stwierdzić, że pojęcie governance w Niemczech zostało dostosowane do specyfiki tego kraju. Jego adaptacja wymusiła stworzenie odpowiednich kryteriów. Istotą governance w Niemczech jest założenie, że samorząd gminny, będący zdecentralizowaną formą administracji państwowej, odgrywa kluczową rolę w zakresie tworzenia form współpracy z innymi podmiotami publicznymi i prywatnymi. Termin governance można zatem traktować szeroko. Po drugie, rozpatrując zakres wzajemnych zależności między podmiotami publicznoprawnymi a prywatnoprawnymi, należy koncentrować się na poszukiwaniu form pośrednich, które stanowią katalizator ich potrzeb i interesów, które pomagają $\mathrm{w}$ doprowadzeniu do postępu społeczno-gospodarczego na danym obszarze.

Odmianą governance jest zatem multi-level governance, czyli zarządzanie wieloszczeblowe. Geneza multi-level governance, jako formy współzarządzania, sięga lat 70. ubiegłego wieku i jest wynikiem procesów regionalizacji i europeizacji1. Pierwotnie termin ten dotyczył głównie poziomu ponadnarodowego i narodowego. Wraz z przeniesieniem polityki rozwoju regionalnego z poziomu centralnego na szczebel krajów związkowych powstała potrzeba stworzenia nowych mechanizmów koordynacji podmiotów funkcjonujących na tym terenie, aby wykorzystać ich potencjał dla postępu społeczno-gospodarczego ${ }^{12}$. Od tej pory sens istnienia systemu politycznego w RFN zaczęto rozpatrywać z perspektywy współpracy podmiotów, które łącząc się, dążą do wypracowania nowej wartości podnoszącej konkurencyjność ich terenu.

Multi-level governance należy łączyć w Niemczech z dwoma określeniami wynikającymi z kryzysu legitymizacji współczesnych instytucji państwowych i demokracji reprezentatywnej, a mianowicie niską efektywnością dostarczanych usług publicznych oraz reprezentacją interesów ${ }^{13}$. Wynika $\mathrm{z}$ tego, że nieskuteczne są rozwiązania oparte na dostarczaniu dóbr i usług publicznych tylko przez administrację władczą. Stracił także na aktualności proces zamawiania u podmiotów prywatnych ich wykonania w ramach nowego zarządzania publicznego (New Public Management), które skupiało się na dążeniu samorządu do osiągnięcia zysku. W New Public Management samorząd prowadził działalność gospodarczą po to, aby chronić swoje mienie, wykorzystując w tym celu rozwiązania z zakresu prawa cywilnego ${ }^{14}$. Model ten oparty jest na administracji świadczącej, której organy jako aktywni aktorzy sfery lokalnej zarządzają mieniem, dostosowując rozwiązania rynkowe do administracji publicznej. Wiąże się z tym kwestia przekroczenia granic, które rozumiane jest jako gromadzenie więcej mienia niż jest potrzebne do realizacji zadań. $Z$ drugiej strony należy je akumulować po to, aby w czasach kryzysu wystarczyło na ciągłe i nieprzerywane zaspokojenie wszystkich potrzeb członków wspólnoty lokalnej.

Poglądy te zainspirował kryzys finansowy gmin w latach 80. XX w. Wśród jego powodów wyróżniono: niewystarczające środki przekazane na realizację zadań przez gminy; za wysokie raty spłaty zadłużenia; spadające zyski z inwestycji; wzrastające wydatki na per-

11 F. Scharpf, Zapiski o teorii zarządzania wielopoziomowego w Europie, „Zarządzanie Publiczne” 2014, nr 4, s. 76-99.

12 L. Giessen, M. Böcher, Rural Governance, forestry, and the promotion of local knowledge: The case of the German rural development programme „Active Regions”, „Small-scale Forestry” 2009, Vol. 8, s. 211-230.

13 M. Strumińska-Kutra, Rola badań społecznych $w$ refleksyjnych procesach metarzadzenia. Zarys perspektywy teoretycznej i metodologicznej, „Zarządzanie Publiczne” 2012, nr 4, s. 17-29.

14 O. Lepsius, Geld als Schutsgut der Eigentumsgarantie, „Juristen Zeitung” 2002, Vol. 757, s. 313-321. 
sonel administracyjny; zbyt dużą ilość przekazanych zadań; brak umiejętnej polityki generowania zysków $\mathrm{z}$ inwestycji; decyzje państwa federalnego i krajów związkowych o podatkach; ograniczenie publicznego zadłużenia w związku z kryteriami z Maastricht (kryteria wejścia do unii gospodarczej i walutowej) oraz koszty zjednoczenia Niemiec ${ }^{15}$.

New Public Management w Niemczech nie przekształciło się w nowe zarządzanie lokalne (New Local Governance), tak jak miało to miejsce w krajach anglosaskich, lecz w nowy model sterowania (NSM - Neues Steurungsmodell). Model ten stanowił oddolną inicjatywę gmin, które bez wsparcia ze strony administracji rządowej podjęły próbę zmiany sposobu swojego działania ${ }^{16}$. NSM został opracowany przez stowarzyszenie na rzecz zarządzania w administracji (Die komunnale Gemeinschaftstelle für Verwaltungsmanagement). Model ten obejmuje pięć postulatów:

- jasne oddzielenie polityki od administracji,

- oddzielenie sfery tworzenia polityk publicznych od bieżącej polityki federalnej,

- wprowadzenie kontraktów na zarządzanie między menedżerami wyższego szczebla a podległymi im jednostkami organizacyjnymi,

- decentralizację zarządzania zasobami administracji,

- powołanie specjalnych jednostek sterujących i monitorujących działania administracji. Nowy kierunek przekształceń $\mathrm{w}$ sferze zarządzania publicznego stworzył podstawę do tego, aby wprowadzić w zakresie wykonania zadań publicznych modele partycypacyjne, które mogą być urzeczywistnione przez multi-level governance.

Źródło multi-level governance tkwi zatem $\mathrm{w}$ zmianie stylu zarządzania $\mathrm{w}$ administracji publicznej, który przejawia się w odchodzeniu od modelu biurokratycznego government na rzecz modelu opartego na różnicowaniu sposobów koordynacji z wykorzystaniem rynków i sieci (governance) ${ }^{17}$. W praktyce przejawia się to m.in. procesami decentralizacji oraz współdziałaniem podmiotów sektora publicznego, prywatnego i społecznego w zakresie rządzenia ${ }^{18}$. Zakres podmiotowy strategii wieloszczeblowego zarządzania w Niemczech obejmuje oprócz jednostek samorządu terytorialnego, także instytucje samorządu gospodarczego jako formy zdecentralizowanej administracji publicznej. Insty tucjami samorządu gospodarczego są izby przemysłowo-handlowe, izby rolnicze oraz izby rzemieślnicze.

\section{Realizacja zadań publicznych w ramach multi-level governance}

Realizacja zadań publicznych $\mathrm{w}$ ramach strategii multi-level governance w Niemczech wiąże się z problemem koordynacji tych działań. Problem, jaki pojawia się w tym względzie, dotyczy wykorzystania specyfiki anglosaskiej koncepcji governance, powstałej dla zdekoncen-

15 A. Mutius von, H.-G. Henneke, Kommunale Finanzausstattung und Verfassungsrecht. Dargestellt am Beispiel der nordrhein-westfälischen Gemeindefinanzierungsgesetze 1983 und 1984, Recinger, Siegburg 1985, s. 33-505.

16 D. Sześciło, Niemiecki Steuerungsmodell. Nowe zarządzanie publiczne w samorządzie lokalnym, „Samorząd Terytorialny" 2012, nr 1-2, s. 42-52.

17 M. Bevir, SAGE Handbook of Governance, SAGE, London 2011, s. 1-529.

18 J. Hausner, Od idealnej biurokracji do zarządzania publicznego, w: Wymiary życia społecznego, red. M. Morody, s. 493515, Wydawnictwo Naukowe Scholar, Warszawa 2007. 
trowanej administracji publicznej (administracji rządowej) przez zdecentralizowane formy administracji państwowej (administracji samorządowej). Governance zakłada funkcjonowanie na jednej płaszczyźnie (lokalnej i regionalnej) podmiotów publicznych (samorządu gminnego) i podmiotów prywatnych. Rodzi to problemy związane z kształtowaniem relacji między tymi instytucjami. Przekładając ten problem na rolę, jaką odgrywa samorząd gminny, warto zastanowić się nad tym, w jakich sytuacjach sprawdza się w zakresie wykonywania zadań publicznych przez podmioty prywatne, a w jakich właściwe są instrumenty nakazowe, a kiedy warto stosować sposoby współzarządzania. Bezpośrednio jest to związane z wykonywaniem zadań w ramach administracji władczej i świadczącej. Te dwa typy przedstawiają funkcje, jakie pełnią organy administracji samorządowej. Administrowanie mieniem polega na zarządzaniu za pomocą form działania właściwych dla prawa administracyjnego. Z kolei gospodarowanie to zarządzanie oparte na formach prawa cywilnego, zakładające równość stron stosunku prawnego, gdzie władcze i jednostronne określenie sytuacji jednego podmiotu prawnego przez drugi jest niedopuszczalne. W tym miejscu należałoby wyjaśnić czym różni się administracja władcza od świadczącej. Pierwsza z nich polega na działaniu opartym na jednostronnych aktach prawnych, które regulują stosunki między podmiotami publicznymi a prywatnymi. Natomiast administracja świadcząca zapewnia usługi komunalne, a do ich wykonania można utworzyć formy prywatnoprawne.

W ramach współzarządzania wielopoziomowego można wyróżnić dwa jego typy. Pierwszy z nich obejmuje funkcjonowanie ograniczonej liczby podmiotów, które zajmują się podobnymi obowiązkami. Istnieją zatem w tym zakresie formalnie zależne od siebie centra decyzyjne, które mają ograniczoną liczbę.

W związku z tym konieczne jest, aby istniała również ograniczona liczba szczebli władzy. Podmioty wykazują się elastycznością w sytuacji powołania ich do rozwiązania określonego problemu. Natomiast drugi układ zakłada działanie licznych organów władzy wypełniających odrębne zadania. Można wówczas mówić o funkcjonowaniu formalnie niezależnych od siebie centrów decyzyjnych, których liczba jest nieograniczona. Nie istnieje w tym względzie również limit szczebli władzy. Podobnie jak w pierwszym typie podmioty charakteryzują się wysoką otwartością i elastycznością w przystąpieniu do rozwiązania problemów, które występują na danym terenie lub które mają na niego znaczących wpływ ${ }^{19}$.

Na podstawie powyższych typów multi-level governance można wyróżnić sposoby realizacji zadań publicznych w zależności od podmiotu publicznoprawnego, który odgrywa najważniejszą rolę w zakresie kreowania ich wykonania. $Z$ jednej strony mogą inicjować tego typu działalność: izby przemysłowe-handlowe, izby rolnicze oraz izby rzemieślnicze. $\mathrm{Z}$ drugiej strony można doszukać się realizacji strategii wieloszczeblowego zarządzania $\mathrm{w}$ ramach struktury zadań publicznych realizowanych przez samorząd gminny. W szczególności mowa w tym względzie o grupie tych zadań publicznych (Gemeinschaftsaufgaben).

Analizując przykładowo działalność izb rolniczych, można przedstawić wykonanie zadania $\mathrm{w}$ zakresie ochrony środowiska $\mathrm{z}$ zastosowaniem multi-level governance. Jak wskazano wyżej, podstawą pierwszego typu multi-level governance jest stworzenie poziomego sojuszu między podmiotami należących do jednej branży, np. ochrony środowiska (np. 
izba rolnicza, jednostki samorządu gminnego, lasy państwowe, stowarzyszenia i fundacje mające w statucie zapis o ochronie środowiska, mieszkańcy obszarów położonych blisko terenów zieleni). Centralnym punktem integracji poziomej w postaci sieci i koalicji jest koncentracja wokół interesu nadrzędnego, jakim jest ochrona środowiska, a nie interesy jednostkowe wymienionych podmiotów. Podstawą formalną sieci są wspólne założenia programowe, zintegrowane strategie i plany rozwoju, które umożliwiają współdziałanie i wdrażanie regionalnych oraz lokalnych projektów. Wymiernym działaniem jest także wspólne przygotowanie programów ochrony środowiska oraz programów ochrony powietrza, a także strategii rozwoju. W celu doprowadzenia do synergii podmiotów administracji publicznej, gospodarki oraz społeczeństwa obywatelskiego niezbędne jest, aby programy i strategie miały wielowymiarowy charakter i wykraczały swoim zasięgiem oddziaływania poza cele do zrealizowania.

Z kolei drugi sposób realizacji multi-level governance został wprowadzony w strukturę zadań publicznych samorządu gminnego w postaci Gemeinschaftsaufgaben. Specyfika tych zadań polega na tym, że na szczeblu federalnym tworzone są ogólne warunki współpracy podmiotów publicznych i prywatnych w zakresie ich realizacji. Następnie warunki te ulegają szczegółowemu doprecyzowaniu na poziomie regionalnym, czyli są dostosowane do specyfiki danego kraju związkowego. W końcowej fazie przekazane są gminom do realizacji jako zadania zlecone. Są to zadania, które mają szerszy niż lokalny wymiar, np. w zakresie poczty, transportu, planowania przestrzennego, nadzoru gospodarczego, finansów, opłat i podatków. Istotną cechą Gemeinschaftsaufgaben jest wzajemne przenikanie się ich wykonania z innymi organami administracji publicznej. Kolejną cechą tych zadań jest wpisanie zasady subsydiarności w ich strukturę. Wykonanie zasady pomocniczości opiera się na tym, że zadania te mogą wykonać albo jednostki samorządu terytorialnego, albo - kiedy one nie są w stanie ich zrealizować - organy administracji rządowej. Warto również dodać, że władze centralne oprócz stworzenia ram współpracy podmiotów publicznych z prywatnymi tworzą specjalne programy, w których wspierają finansowo inicjatywy oddolne obejmujące swoim zakresem działania kilka różnych podmiotów ${ }^{20}$.

Wskutek podjętych działań powstaje nowy model zarządzania sprawami publicznymi. Jego bezpośrednimi konsekwencjami jest zmiana strategii rozwoju regionalnego, która oparta jest na działalności oddolnych instytucji doprowadzających do podniesienia efektywności realizacji określonych zadań na danym terenie ${ }^{21}$.

W omówionych powyżej typach multi-level governance następuje integracja podmiotów lokalnych i regionalnych oraz ich potencjału, czyli informacji, wiedzy, kapitału ludzkiego oraz środków finansowych. Dzięki temu możliwe jest efektywniejsze rozwiązanie spraw występujących na danym obszarze. Pośrednią korzyścią jest także wzrost akceptacji władzy publicznej oraz realizowanej przez nią polityki ${ }^{22}$.

20 B. Dolnicki, Samorząd terytorialny, Zakamycze, Kraków 2006, s. 1-402.

21 L. Giessen, Regional Governance für ländliche Räume - innovativer Ansatz, politischer Gegenwind und der Weg vorwärtz, „Raumforschung und Raumordnung” 2010, Vol. 68, s. 3-14.

22 Ibidem. 
Z powyższej analizy wynika, że analiza roli samorządu gminnego $w$ multi-level governance pokazuje, że zadania publiczne wykonywane są według następujących prawidłowości:

- pionowa i pozioma dezagregacja roli państwa prowadzi do wieloszczeblowości (wielopoziomowości) władzy, dzielenia się odpowiedzialnością i zachodzeniem na siebie kompetencji różnych podmiotów,

- występuje możliwość funkcjonowania ograniczonej liczby niezależnych od siebie i elastycznych (powołanych wedle aktualnych potrzeb) centrów decyzyjnych,

- państwo występuje jako pośrednik w powstawaniu pionowych i poziomych powiązań sieciowych i we wzmacnianiu znaczenia podmiotów niepaństwowych, a zarazem jako koordynator takich powiązań,

- występują pośrednie formy organizacyjne między rynkiem a organizacjami,

- rośnie znaczenie relacji (interakcji) między podmiotami uczestniczącymi w procesach rządzenia, które w dużej mierze funkcjonują dzięki zaufaniu,

- następuje zmiana formy koordynacji z nakazowej na negocjacje,

- wzrasta znaczenie instytucji,

- zwiększa się znaczenie podejścia oddolnego do realizacji zadań publicznych i obszaru gmin jako miejsca wymiany wiedzy i informacji ${ }^{23}$.

\section{Formy organizacyjno-prawne wykonywania zadań publicznych w ramach multi-level governance}

Analizując relacje między organami administracji państwowej a podmiotami prywatnymi w kontekście wykonywania zadań publicznych, należy zastanowić się nad mechanizmem koordynacji działań zbiorowych. Pojęcie to wprowadził do nauki polskiej, za Walterem W. Powellem, Jerzy Hausner, który wyodrębnił w tym względzie trzy takie mechanizmy: organizacje (hierarchia), rynki (przedsiębiorstwa) oraz sieci (formy pośrednie, hybrydowe). Ich cechy zostały przedstawione w poniższej tabeli.

Tabela 1. Typologia sposobów koordynacji działań

\begin{tabular}{|l|l|l|l|}
\hline \multicolumn{1}{|c|}{ Cecha } & \multicolumn{1}{c|}{ Organizacje } & \multicolumn{1}{c|}{ Rynki } \\
\hline Podstawa normatywna & Narzucone reguły & Kontrakty & Konwencje \\
\hline Charakter relacji między uczestnikami & Dominacja - podporzadkowanie & Konkurencja i współpraca & Partnerstwo \\
\hline Podstawowe instrumenty & Administracyjne & Ekonomiczne & Komunikacyjne \\
\hline Sposoby rozwiązywania konfliktów & Nakaz administracyjny - nadzór & $\begin{array}{l}\text { Negocjacje - egzekwowanie } \\
\text { roszczeń na drodze sądowej }\end{array}$ & $\begin{array}{l}\text { Negocjacje oparte na zasadzie } \\
\text { wzajemności i arbitraż }\end{array}$ \\
\hline Preferencje i decyzje użytkowników & Zależne & Niezależne & Współzależne \\
\hline Zdolność adaptacyjna & Słaba & Wysoka & Średnia \\
\hline
\end{tabular}

Źródło: Opracowanie własne na podstawie: J. Hausner, Zarządzanie publiczne, Wydawnictwo Naukowe Scholar, Warszawa 2008; W.W. Powell, Neither market or hierarchy. Network forms of organization, „Research in Organizational Behaviour” 1990, Vol. 12, s. 295-336.

23 P. Kopyciński, Mechanizm koordynacji w polityce innowacyjnej w świetle koncepcji współzarządzania wielopoziomowego (multi-level governance). Przykład województwa małopolskiego i świętokrzyskiego, „Zarzadzanie Publiczne” 2014, nr 4, s. 31-46. 
Współzarządzanie na kilku poziomach, lokalnym i regionalnym, oraz na różnych szczeblach władzy wymaga natomiast bardziej złożonego podtypu governance, jakim jest jego forma sieciowa multi-level governance.

O ile sposoby organizacji koordynacji działań takie jak: organizacje (hierarchia) i rynek w RFN są dobrze wykształcone, o tyle w odniesieniu do sieci następuje ich ciągła ewolucja. Warto w tym względzie wspomnieć, że formy sieciowe powstają wtedy, gdy istnieje potrzeba poszukiwania elastycznych rozwiązań, które odpowiadałyby zmianom w systemie. Formy sieciowe charakteryzują się zatem partnerskimi relacjami utrzymywanymi przez zainteresowane strony, w wyniku których aktorzy dobrowolnie zrzekają się części swojej autonomii w celu osiągnięcia zakładanych korzyści. Konflikty są wykorzystywane za pomocą negocjacji, przy wykorzystaniu odpowiednich narzędzi komunikacyjnych. Decyzje uczestników pozostają od siebie współzależne. Mimo że ich zdolność adaptacyjna jest mniejsza od rynku, to ma w tym względzie przewagę nad organizacjami ${ }^{24}$.

Omawiając zakres podmiotowy, nie można zapomnieć o zakresie przedmiotowym $\mathrm{mul}$ ti-level governance w Niemczech. Wynika on z traktowania tej koncepcji jako formy współpracy podmiotów w ramach sieci wzajemnych zależności. Zakres przedmiotowy multi-level governance obejmuje przykładowo następujące zadania: bioenergetykę, ochronę środowiska, upowszechnienie kultury, turystykę i rekreację oraz promowanie kultury fizycznej ${ }^{25}$.

Zakres przedmiotowy to jednak nie tylko zadania, lecz także sposób ich realizacji. $\mathrm{W}$ niemieckiej literaturze przedmiotu realizacja zadań $\mathrm{w}$ ramach multi-level governance została oparta na zasadzie partnerstwa (Partnerschaftsprinzip). Zasada ta przewiduje, że najpełniejszymi formami koordynacji interesów publicznych będą aglomeracje miejskie w postaci regionów metropolitarnych, stanowiące strukturę organizacyjną na określonym terenie i znamienne dla nich formy współpracy, czyli związki publicznoprawne i spółki prawa handlowego oraz modele partnerstwa publiczno-prywatnego w postaci:

- BOO - Build-Own-Operate, czyli budowanie-własność-eksploatacja,

- BOT - Build-Operate-Transfer, czyli budowanie-eksploatacja-przekazanie,

- BTO - Build-Transfer-Operate, czyli budowanie-przekazanie-eksploatacja,

- DBFO - Design-Build-Finance-Operate, czyli projektowanie-budowanie-finansowanie-eksploatacja.

W niemieckiej literaturze przedmiotu wśród zalet modeli partnerstwa publiczno-prywatnego można wymienić: złamanie samorządowego monopolu na dostarczanie dóbr i usług komunalnych; odpolitycznienie zarządzania w świadczeniu usług publicznych dla danej społeczności; rozwój gospodarczy bez obciążania długiem budżetu jednostek samorządu terytorialnego i tym samym budżetu państwa oraz wprowadzenie nowych technologii przez podmioty prywatne. Wśród ich zalet można wskazać na: oszczędność w wydatkach podmiotu publicznego, podniesienie standardu świadczonych usług czy poprawę stanu infrastruktury ${ }^{26}$. Natomiast do wad zalicza się: ryzyko wzrostu kosztów, wystąpie-

\section{P. Kopyciński, op. cit.}

25 L. Giessen, op. cit.

26 D. Richter, Kommunales Vermögen und seine Verwaltung, w: Recht der Kommunalfinanzen. Abgaben, Haushalt, Finanzausgleich, red. H.-G. Henneke, C.H. Beck, München 2006, s. 738-768. 
nie zmian technologicznych, konkurencję, ograniczenie wpływu samorządów lokalnych na wybór inwestycji, ograniczenie dostępności do usług oraz wzrost opłat za korzystanie z obiektów infrastrukturalnych ${ }^{27}$. W Niemczech najczęściej występuje model BOT - BuildOperate-Transfer, czyli budowanie-eksploatacja-przekazanie.

\section{Rola samorządu gminnego w multi-level governance w RFN}

Bez względu na poziom, na którym rozpatruje się pojęcie multi-level governance oznacza ono współzarządzanie organów administracji publicznej z innymi strukturami organizacyjnymi, które funkcjonują w jego otoczeniu, w celu regulacji procesów społeczno-gospodarczych. Termin ten obejmuje także formę koordynacji polityk publicznych, które decydują o tym, w jaki sposób funkcjonują przedsiębiorcy, stowarzyszenia, fundacje oraz osoby fizyczne $^{28}$. W związku $\mathrm{z}$ tym nasuwa się pytanie, w jaki sposób realizowana jest strategia multi-level governance na poziomie gminy?

Jeżeli potraktuje się szczebel gminny jako jeden $\mathrm{z}$ poziomów, z którego podmioty biorą udział w współzarządzaniu, to staje się on płaszczyzną koordynacji sieciowej. W państwach, w których administracja publiczna oparta jest na decentralizacji, to organy państwa pełnią wiodącą rolę w zakresie tworzenia płaszczyzny współpracy. Gminy są głównym elementem systemu sieciowego, a pozostałe podmioty gospodarcze i społeczne znajdują się w ich otoczeniu instytucjonalnym. Występują one wówczas jako układy instytucjonalne, które reprezentując określone potrzeby i interesy, uczestniczą w procesie współdecydowania i współdziałania.

Istotnym układem instytucjonalnym w ramach wieloszczeblowego zarządzania są izby przemysłowo-handlowe. Tylko w Niemczech są one partnerem dla samorządu terytorialnego i jako organy państwa w pełni przedstawiają problemy przedsiębiorców. Samorządy gminne oraz izby przemysłowo-handlowe w Niemczech jako korporacje publicznoprawne mogą zatem pełnić funkcję pośrednika w powstawaniu pionowych i poziomych powiązań sieciowych oraz we wzmacnianiu znaczenia podmiotów niepaństwowych ${ }^{29}$. Należy w tym względzie zwrócić uwagę na podejście oddolne (bottom-up) przejawiające się w różnych formach partnerstw, w których zasadnicze znaczenie ma zaufanie między podmiotami.

Szczególną rolę pełni w tym zakresie samorząd gminny. Jako organizacja społeczno-gospodarcza, funkcjonująca na danym terenie, obejmuje instytucje, rynek oraz wzajemne relacje. W ramach zbioru instytucji wyróżnia się przedsiębiorców, stowarzyszenia, fundacje oraz mieszkańców. Rynek stanowi zatem przedmiot i granicę ich działania. Pomiędzy nimi zachodzą sprzężenia zwrotne. Działanie jest zarówno skutkiem, jak i bodźcem do kolejnej interakcji. W ten sposób powstaje sieć wzajemnych zależności. Podmioty funkcjonujące na tym samym obszarze łączy nie tylko podobieństwo interesów, lecz także rozwiązywanie

27 E. Książek, Partnerstwo publiczno-prywatne, w: Prawno-organizacyjne aspekty zarządzania w gminie, red. A. Kożuch, M. Stych, Wydawnictwo Akademii im. Jana Długosza w Częstochowie, Częstochowa 2011, s. 1-266.

28 P. Kopyciński, op. cit.

29 C. Ansell, op. cit. 
tych samym problemów. Nasuwa się w związku z tym pytanie, w jaki sposób gmina powinna koordynować przestrzeń? Podmioty te działają na różnych poziomach, dlatego nie wystarczy tylko nimi zarządzać. Trzeba uwzględnić poziomy oddziaływania, czyli doprowadzić do współzarządzania (governance), które obejmie wszystkie poziomy interakcji a więc współzarządzanie wielopoziomowe (multi-level governance).

Wynika z tego, że koncepcja współzarządzania wielopoziomowego (multi-level governance) znajduje swoje zastosowanie w sytuacji, kiedy należy wyznaczyć granice i sposoby interwencji władz publicznych w niwelowaniu skutków zawodności rynkowej oraz dążeniu do rozwoju lokalnego. Oprócz tego może posłużyć także w sytuacji, kiedy zasięg zadania publicznego wykracza poza granice gminy. Wówczas stanowi strategię koordynacji podmiotów publicznych i prywatnych.

W ramach wieloszczeblowego zarządzania wskazuje się na potrzebę ujmowania problemów rozwojowych danego terytorium z uwzględnieniem racji wszystkich aktorów, łącząc przy tym aspekty społeczno-gospodarcze z przestrzennymi. Takie podejście pozwala na partycypacyjne określenie akceptowanego poziomu, a także sposobu świadczenia usług publicznych.

Można zatem stwierdzić, że governance odpowiada na pytanie, w jaki sposób zastosować współzarządzanie, a w jakich sytuacjach pozostawić coś dla rynku, czyli podmiotów prywatnych, ale także dla administracji świadczącej czy administracji władczej. Multi-level governance staje się zatem trzecią drogą pomiędzy rozwiązaniami charakterystycznymi dla podmiotów publicznoprawnych wykonujących swoje zadania w ramach powierzonego w ustawie władztwa administracyjnego, a organizacji prywatnoprawnych działających w obrocie rynkowym.

\section{Podsumowanie}

Z powyższej analizy można wyciągnąć następujące wnioski:

1. Decentralizacja administracji publicznej umożliwia rozszerzenie multi-level governance na inne organy państwa (czyli publicznoprawne izby przemysłowo-handlowe, izby rolnicze, izby rzemieślnicze).

2. W Niemczech występuje koncentracja na formach wykonywania zadań publicznych, które zakładają partycypację podmiotów prywatnych w ich realizacji.

3. Powstanie multi-level governance w Niemczech oparte jest na działaniach odgórnych i następuje od kraju związkowego do gmin (top-down). Tworzenie układu sieciowego wynika wówczas z przekonania władz państwowych o efektywniejszej realizacji zadań publicznych dzięki współpracy z podmiotami prywatnymi, których działania moderowane są przez podmioty władcze.

4. Multi-level governance na poziomie lokalnym jest poprzedzone regional governance.

5. Na poziomie lokalnym multi-level governance w Niemczech jest wprowadzone w strukturę zdecentralizowanej administracji publicznej za pośrednictwem specjalnego typu zadania publicznego (Gemeinschaftsaufgaben). 
6. W Niemczech istnieje silna potrzeba instytucjonalizacji i formalizacji struktury wieloszczeblowego zarządzania. Przejawem tego jest region metropolitarny oraz oparcie jego funkcjonowania na formach współpracy publicznoprawnej w postaci związków publicznoprawnych i prywatnoprawnych w postaci spółek prawa handlowego.

\section{Bibliografia}

Ansell C., The networked policy. Regional development in Western Europe, „Governance” 2000, Vol. 13, Issue 2, s. 279-291.

Adamaschek B., Region-Regional Governance-Regionalentwicklung, w: idem, Regional Governance von der kommunalen zur regionalen Strategie, Bertelsmann, Gütersloh 2003, s. 1-123.

Bevir M., SAGE Handbook of Governance, SAGE, London 2011.

Böcher M., Instrumentenwandel in der Umwelt- und Naturschutzpolitik und der Politik zur integrierten ländlichen Entwicklung. Theoretische Grundlagen und Strategien der Praxisumsetzung, Dissertation, Göttingen 2008.

Denters B., Rose L., Towards local governance?, w: Comparing Local Governance. Trends and Developments, red. B. Denters, L. Rose, Palgrave Mac Millan, New York 2005, s. 46-62.

Dolnicki B., Samorząd terytorialny, Zakamycze, Kraków 2006.

Fürst D., Regional Governance - ein neues Paradigma der Regionalwissenschaften?, „Raumforschung und Raumordnung" 2001, No. 59, s. 370-380.

Fürst D. Regional Governance, w: Governance - Regieren in komplexen Regelsystmen, red. A. Benz, VS Verlag für Sozialwissenschaften, Wiesbaden 2004, s. 49-69.

Giessen L., Regional Governance für ländliche Räume - innovativer Ansatz, politischer Gegenwind und der Weg vorwärtz, „Raumforschung und Raumordnung” 2010, Vol. 68, s. 3-14.

Giessen L., Böcher M., Rural Governance, forestry, and the promotion of local knowledge. The case of the German rural development programme „Active Regions”, „Small-scale Forestry” 2009, Vol. 8, s. 211-230.

Hausner J., Od idealnej biurokracji do zarządzania publicznego, w: Wymiary życia społecznego, red. M. Morody, s. 493-515, Wydawnictwo Naukowe Scholar, Warszawa 2007.

Hausner J., Zarzadzanie publiczne, Wydawnictwo Naukowe Scholar, Warszawa 2008.

Hooghe L., Marks G., Types of multi-level governance, „European Integration Online Paper” 2001, Vol. 5, s. 1-24.

Jessop B., Promowanie dobrego rządzenia i ukrywanie jego słabości. Refleksja nad politycznymi paradygmatami i politycznymi narracjami w sferze rządzenia, „Zarządzanie Publiczne” 2007, nr 2, s. 5-25.

Kaufmann D., Kraay A., Mastruzzi M., Governance Matters VII Governance Indicators for 19962007, DC World Bank, Washington 2009.

Kopyciński P., Mechanizm koordynacji w polityce innowacyjnej w świetle koncepcji współzarządzania wielopoziomowego (multi-level governance). Przykład województwa małopolskiego i świętokrzyskiego, „Zarzadzanie Publiczne” 2014, nr 4, s. 31-46.

Książek E., Partnerstwo publiczno-prywatne, w: Prawno-organizacyjne aspekty zarządzania $w$ gminie, red. A. Kożuch, M. Stych, Wydawnictwo Akademii im. Jana Długosza w Częstochowie, Częstochowa 2011, s. 1-266. 
Kuhlmann S., Bogumil J., Grohs S., Evaluating Administrative Modernization In German Local Governments. Success of Failure of the „New Steering Model?”, „Public Administration Review” 2008, Vol. 5, s. 851-863.

Kuhlmann S., Bogumil J., Grohs S., Ohm A., Zehn Jahre Neues Steuerungsmodell. Eine Bilanz kommunaler Verwaltungsmodernisierung, Berlin, Edition Sigma, Berlin 2007.

Lepsius O., Geld als Schutsgut der Eigentumsgarantie, „Juristen Zeitung” 2002, Vol. 757, s. 313-321.

Mutius A. von, Henneke H.-G., Kommunale Finanzausstattung und Verfassungsrecht. Dargestellt am Beispiel der nordrhein-westfälischen Gemeindefinanzierungsgesetze 1983 und 1984, Recinger, Siegburg 1985.

Powell W.W., Neither market or hierarchy. Network forms of organization, „Research in Organizational Behaviour" 1990, Vol. 12, s. 295-336.

Richter D., Kommunales Vermögen und seine Verwaltung, w: Recht der Kommunalfinanzen. Abgaben, Haushalt, Finanzausgleich, red. H.-G. Henneke, C.H. Beck, München 2006.

Scharpf F., Zapiski o teorii zarządzania wielopoziomowego w Europie, „Zarządzanie Publiczne” 2014, nr 4, s. 76-99.

Strumińska-Kutra M. Rola badań społecznych $w$ refleksyjnych procesach metarzadzenia. Zarys perspektywy teoretycznej i metodologicznej, „Zarządzanie Publiczne” 2012, nr 4, s. 17-29.

Sześciło D., Niemiecki Steuerungsmodell. Nowe zarządzanie publiczne w samorzadzie lokalnym, „Samorząd Terytorialny" 2012, nr 1-2, s. 42-52.

\section{The role of local government in multi-level governance in Federal Republic of Germany}

\section{SUMMARY}

The aim of this article is to present how the concept of multi-level governance was adopted to the German local government. The author made two arrangements. Firstly, the emergence of multi-level governance in Germany is based on top-down activities, which occur between federal states and communities. Creating network systems results from the conviction of the state authorities about fulfillment of public tasks, which is more effective with private organizations, which are moderated by public entities. Secondly, before implementing multi-level governance on local level, the regional governance was posed on the level of federal states, which is the adjustment of governance's concept to the specify of federal states. Notwithstanding, the most important result from this article is the fact, that multi-level governance was implemented to the structure of local government in the characteristic type of public task (Gemeinschaftsaufgaben).

\section{KEYWORDS}

Governance, Multi-level Governance, local government, Germany 
